Proceedings

of the

Edinburgh

Mathematical

Society 


\title{
PROCEEDINGS
}

OF THE

EDINBURGH MATHEMATICAL SOCIETY

\author{
EDITORIAL BOARD
}

C. ATHORNE (Reviews Editor)
R. HEPWORTH (Topology)
J. MARTENS (Algebraic Geometry)
M. QUICK (Algebra and Deputy Convenor)
J. C. ROBINSON (Differential Equations)
S. SIERRA (Algebra and Representation
Theory)
S. THERIAULT (Convenor of Editorial Board)

M. TODD (Ergodic Theory)
S. FOSS (Probability)

W. KLINGENBERG (Differential Geometry)

M. PRAMANIK (Harmonic Analysis)

G. ROBERTS (Model Theory and Number Theory)

G. M. STALLARD (Complex Analysis and Complex Dynamics)

R. TIMONEY (Functional Analysis)

\section{CONSULTING EDITORS}

\author{
P. F. BAUM \\ Pennsylvania State University \\ L. JEFFREY \\ University of Toronto \\ F. OTTO \\ Max-Planck-Institut \\ für Mathematik in den \\ Naturwissenschaften
}

\author{
F. BOGOMOLOV \\ New York University \\ R. KESSAR \\ City University London \\ M. POLLICOTT \\ University of Warwick \\ W. WINTER \\ Universität Münster
}

\author{
R. COHEN \\ Stanford University \\ S. MÜLLER \\ Universität Bonn \\ A. REID \\ Rice University
}

Subscriptions Proceedings of the Edinburgh Mathematical Society (ISSN 0013-0915) is published in February, May, August and November. Four parts form a volume. The subscription price, including electronic access, of volume 61 (2018) is $£ 349$ net (USA, Canada and Mexico US\$666). Prices include delivery by air, where appropriate. Orders, which must be accompanied by payment, may be sent to any bookseller, subscription agent or direct to the publisher: Cambridge University Press, The Edinburgh Building, Shaftesbury Road, Cambridge CB2 8RU; or in the USA, Canada and Mexico: Cambridge University Press, 32 Avenue of the Americas, New York, NY 10013-2473, USA. EU subscribers (outside the UK) who are not registered for VAT should add VAT at their country's rate. VAT registered subscribers should provide their VAT registration number. Japanese prices for institutions are available from Kinokuniya Company Ltd, PO Box 55, Chitose, Tokyo 156, Japan. The Proceedings are also available online only for a subscription price of $£ 280$ (USA, Canada and Mexico US\$552).

Back numbers Series I comprised forty-four volumes published from 1884 to 1926. Series II started in 1927 and reached its sixtieth volume in 2017.

Online access to all of these volumes, except the ten most recent, is freely available via Cambridge Journals Online at http://journals.cambridge.org/PEM. Subscribers to current online issues of Proceedings of the Edinburgh Mathematical Society will also have access to the ten most recent volumes as part of their current subscription.

Information regarding printed back numbers of Series I and Volumes 1-14 of Series II is available by searching under Edinburgh Mathematical Society at http://www.periodicals.com. Print copies of the current volume and earlier volumes in Series II (from Volume 15 onwards) can be obtained from Cambridge University Press at the above address.

Copying This journal is registered with the Copyright Clearance Center, 222 Rosewood Drive, Danvers, MA 01923, USA. Organizations in the USA who are also registered with CCC may therefore copy material (beyond the limits permitted by sections 107 and 108 of US Copyright Law) subject to payment to CCC of the per-copy fee of $\$ 16$. This consent does not extend to multiple copying for promotional or commercial purposes. Code 0013-0915/2004 \$16. ISI Tear Sheet Service, 3501 Market Street, Philadelphia, PA 19104, USA, is authorized to supply single copies of separate articles for private use only. Organizations authorized by the Copyright Licensing Agency may also copy material subject to the usual conditions. For all other use, permission should be sought from Cambridge University Press.

For further information on Proceedings of the Edinburgh Mathematical Society or other Press titles access http://journals.cambridge.org/action/displayJournal?jid=PEM or journals.cambridge.org.

COPYRIGHT C 2018 THE EDINBURGH MATHEMATICAL SOCIETY

The Edinburgh Mathematical Society (EMS) is a registered Scottish Charity (number SC000241) 